\title{
A STUDY ON HISTOPATHOLOGICAL AND CLINICAL EVALUATION OF NECK SWELLINGS IN SURGICAL OUTPATIENTS- AN OBSERVATIONAL STUDY
}

\section{G. Padmasree 1}

1 Professor and HOD, Surgery, ACSR Government Medical College, Nellore, Dr. NTR University of Health Sciences (Affiliated), Vijayawada, Andhra Pradesh, India.

ABSTRACT
BACKGROUND
Neck swelling is a common presentation in the course of number of diseases. Since neck swelling is not a manifestation of a single
disease, diagnosis becomes very difficult and it requires a strong knowledge about the differential diagnosis of neck swellings.
The present study is undertaken with an aim of finding the common aetiologies of neck swellings in a surgical outpatient
setting and also assess the usefulness of Fine Needle Aspiration Cytology (FNAC) and ultrasonography in swellings of neck.

\section{MATERIALS AND METHODS}

The study includes 100 patients with neck swelling attending the surgical outpatient department of a tertiary care hospital. Inclusion criteria- Patients of age $>15$ yrs. presenting with asymptomatic/ symptomatic neck swellings to the surgical outpatient department of a tertiary care Government General Hospital. Samples of FNAC were taken from the swelling and sent for cytology. Ultrasonography was performed for the neck swelling and the results were interpreted in correlation with cytology.

\section{RESULTS}

Thyroid lesions accounted for the majority (57\%) followed by lymph node enlargement (27\%). Benign lesions were most common, of which thyroid goitres were more common in female sex. The most common lymph node lesion is tuberculous/ granulomatous lymphadenitis. In toto malignant lesions accounted for $23 \%$ of cases and their incidence rose sharply after $4^{\text {th }}$ decade.

\section{CONCLUSION}

The most common benign lesion was nodular goitre, inflammatory lesion was thyroiditis, most common malignant lesion was metastatic secondaries of neck and papillary carcinoma thyroid which was more common in young females.

\section{KEY WORDS}

Neck Swelling, Thyroid Lesion, Lymph Node Lesion, Benign Lesion, Malignant Lesion.

HOW TO CITE THIS ARTICLE: Padmasree G. A study on histopathological and clinical evaluation of neck swellings in surgical outpatients- an observational study. J. Evolution Med. Dent. Sci. 2018;7(35):3851-3857, DOI: 10.14260/jemds/2018/863

\section{BACKGROUND}

Neck swellings are frequently encountered in the clinical practice and the cause is usually benign. In general practice inflammatory lymph nodes are the most common cause, mostly with tuberculous aetiology in Indian environment due to malnourishment and poor socioeconomic status. ${ }^{1}$ However, the lump may be the presentation of more serious disease (ex-malignancy or chronic infection) and so a thorough assessment and diagnosis are essential. If there is any doubt as to the cause, then the patient should be reviewed and/ or referred for specialist assessment. Patients over the age of 40 are more likely to have a neoplastic cause. Inflammatory, congenital and traumatic causes are more common in younger patients, but neoplasm should still be borne in mind. ${ }^{2}$ Fine Needle Aspiration Cytology (FNAC) is a simple, quick and cost-effective method to sample superficial masses found in the head and neck. ${ }^{3}$

'Financial or Other Competing Interest': None.

Submission 21-07-2018, Peer Review 14-08-2018,

Acceptance 20-08-2018, Published 27-08-2018.

Corresponding Author:

Dr. G. Padmasree,

D/No. 4-23-4, Sanjay Gandhi Colony,

$1^{\text {st }}$ Line, Opposite Men's Medical Hostel,

Guntur-522007, Guntur District,

Andhra Pradesh, India.

E-mail: padmasri155155@gmail.com

DOI: $10.14260 /$ jemds $/ 2018 / 863$
The technique is performed in the outpatient department and causes minimal trauma to the patient. An early differentiation of benign from malignant pathology is beneficial, as it greatly influences the planned treatment. ${ }^{4}$ It can be both diagnostic and therapeutic in cystic swellings. ${ }^{5}$ It is helpful for the diagnosis of salivary gland tumours where it can differentiate between a malignant and a benign tumour with over $90 \%$ accuracy. ${ }^{6}$ FNAC is particularly helpful in the work-up of cervical masses and nodules, because biopsy of cervical swelling should be avoided unless all other diagnostic modalities have failed to establish a diagnosis. ${ }^{7}$ FNAC does not give the same architectural detail as histology, but it can provide cells from the entire lesion as many passes through the lesion can be made while aspirating. ${ }^{8}$

Two new dimensions of medical practice are non-invasive diagnosis and cost control. UItrasonography qualifies eminently in regards. While there have been many reports on its use in thyroid diseases, there are few reports on its general use in the diagnosis of head and neck diseases. Ultrasonography gives accurate information as to the form and content of cervical masses and enables to distinguish solid from cystic lesions. It may also alert us to the probabilities of malignant versus benign nature of neck swellings.

This study is an effort to assess the incidence of various swellings in neck through clinical examination and usefulness of FNAC as well as ultrasonography. 


\section{Aims and Objectives}

- The primary objective of this study is to elucidate the incidence and distribution of various aetiologies in the patients presenting with neck swellings and study the cause of neck swellings in our surgical outpatient department.

- The second objective is to assess the usefulness of FNAC and Ultrasonography of neck in the diagnosis of neck masses in the outpatient department.

\section{MATERIALS AND METHODS}

After Institutional Ethics Committee approval and written and informed consent, this hospital-based descriptive study in the setting of outpatient department of general surgery in a tertiary care Govt. General Hospital was carried out from December 2014 to 2016 in a sample of 100 patients who presented with neck swellings to the OPD of surgery department.

\section{Inclusion Criteria}

Patients of age > 15 yrs. presenting with asymptomatic/ symptomatic neck swellings, patients belonging to both sexes.

\section{Exclusion Criteria}

Patients presenting with congenital anomalies, vascular anomalies, patients with bleeding diathesis, pregnant patients.

\section{Method of Collection of Data}

Data was collected using a detailed well-designed proforma. Detailed history was taken, and thorough physical examination was carried out and basic relevant investigations like routine blood investigations including $\mathrm{Hb} \%$, TC, DC, ESR, Blood Sugar, Serum Creatinine, Serum Bilirubin, Viral markers- HIV 1/2, HBsAg, HCV, etc. were done in the OPD to arrive at a provisional diagnosis. All the cases of neck swellings were sent to Department of Pathology, where fine needle aspiration cytology (FNAC) will be done with 2123-G needle attached to the $10 \mathrm{~mL}$ plastic disposable syringe. All the patients were also investigated by ultrasonography of neck to determine the position of the swelling and its relation to vital structures and other important features of the swellings. After completion of FNAC and USG of all the neck swellings, the findings and results will be analysed and the pattern of lesions of the neck swellings will be compared to other studies.

\section{Statistical Analysis}

Data was analysed using descriptive statistics. Data is expressed as percentage or absolute numbers.

\section{RESULTS}

There were 61 females and 39 males between 15 and 84 yrs. showing a female preponderance (1.56: 1). Sex distribution is mentioned in Figure 1 and age wise distribution of swellings was represented in Figure 2. Of the 100 neck swellings when categorised based on tissue of origin, there is clear preponderance of thyroid swellings accounting to $57 \%$ followed by swellings of lymph nodes $27 \%$, then $15 \%$ contributed by soft tissue swellings (lipoma, abscess, soft tissue tumours). Lastly with $1 \%$ incidence is salivary gland swelling. They were represented in Table 1.
Based on type of lesions the data regarding neck swelling, it was deducted that most of the neck swellings were benign (43\%) followed by inflammatory (34\%) swellings. Malignant swellings occupied the $3^{\text {rd }}$ place amongst the neck swellings. Benign lesions were most common, of which thyroid goitres were more common in female sex (8.5:1) that is represented in Table 1, Table 2 and Figure 3 and Figure 4. The most common lymph nodal lesion is tuberculosis/ granulomatous lymphadenitis was more common in males (10: 1) represented in Table 6. In toto malignant lesions accounted for $23 \%$ of cases and their incidence rose sharply after $4^{\text {th }}$ decade that is represented in Table 2 and Figure 5. The most common benign lesion was nodular goitre, inflammatory lesion was thyroiditis (Table 6 and Figure 8). Most common malignant lesion was metastatic secondaries of neck and papillary carcinoma thyroid which was more common in young females as represented in Table 7. In segment of people with HIV positive status, which occupied $10 \%$ of the sample TB lymphadenitis was more common $(70 \%)$ as represented in Figure 9.

FNAC is an easy and suitable tool for the assessment of patients with neck swellings in the outpatient clinics. On ultrasonography, malignant lesions were hyperechoic or of heterogeneous signal intensity. Benign lesions showed predominantly hypoechoic character. Multinodular goitre of thyroid showed nodular appearance with mixed echogenic character. Ultrasonography is a pretty useful tool to distinguish cystic swelling from solid ones and to determine their location. Figures 10 to 15 represent the clinical photographs of the patients with different neck swellings.

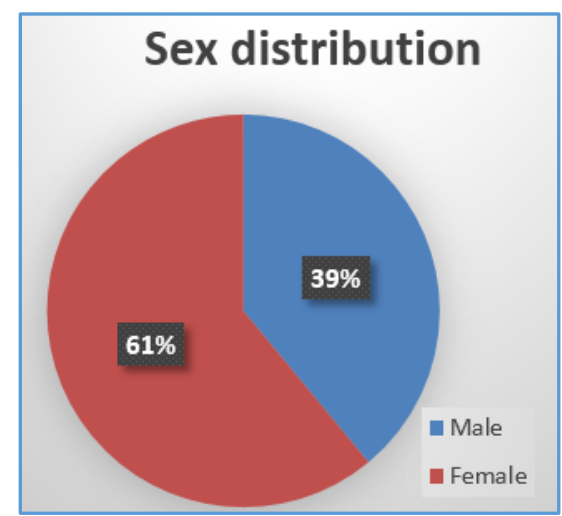

Figure 1. Sex distribution of Neck Masses

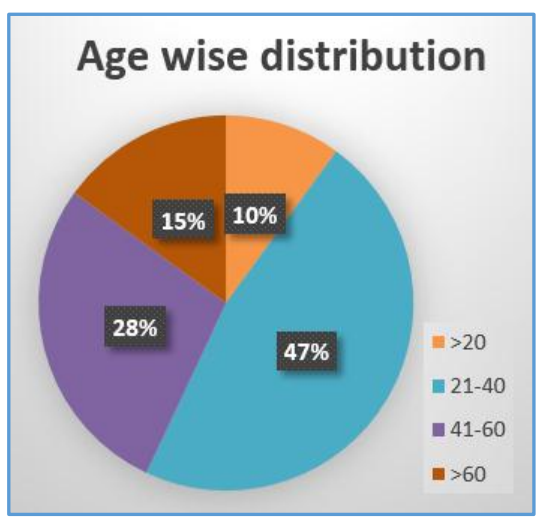

Figure 2. Age distribution of Cases

In the study the patient's age ranged from 15 - 84 years, the mean age being 41.85 years. 


\begin{tabular}{|c|c|}
\hline Tissue of Origin & Incidence N= 100 \\
\hline Thyroid & $57 \%(57)$ \\
\hline Lymph nodes & $27 \%(27)$ \\
\hline Soft tissue & $15 \%(15)$ \\
\hline Salivary & $1 \%(1)$ \\
\hline Total & $\mathbf{1 0 0}$ \\
\hline Table 1. Incidence of Neck Swellings based on Tissue of \\
Origin \\
\hline
\end{tabular}

Data expressed as percentage and absolute number.

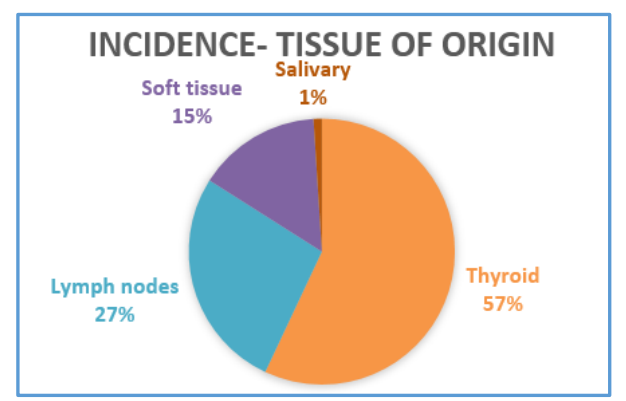

Figure 3. Incidence of Neck Swellings based on Tissue of Origin

\begin{tabular}{|c|c|}
\hline Type of Lesion & $\mathrm{N}=\mathbf{1 0 0}$ \\
\hline Inflammatory & $34 \%$ \\
\hline Benign & $43 \%$ \\
\hline Malignant & $23 \%$ \\
\hline \multicolumn{2}{|c|}{$\begin{array}{l}\text { Table 2. Distribution of Neck Swellings } \\
\text { based on the type of Lesion }\end{array}$} \\
\hline
\end{tabular}

Data expressed as percentage.

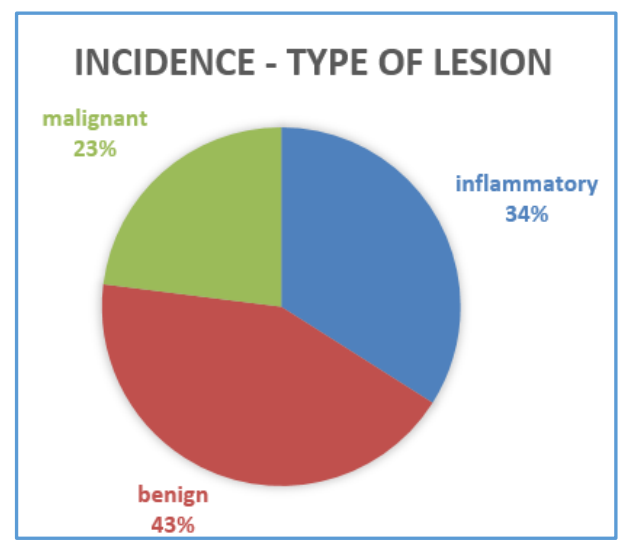

Figure 4. Incidence of Neck Swellings based on type of Lesion

\begin{tabular}{|c|c|c|}
\hline Tissue of Origin & Pathology & $\mathrm{N}=\mathbf{1 0 0}$ \\
\hline \multirow{5}{*}{$\begin{array}{l}\text { Lymph nodes } \\
\qquad(27 \%)\end{array}$} & TB/ Granulomatous LN & $11 \%$ \\
\hline & Reactive lymphadenitis & $4 \%$ \\
\hline & Non-Hodgkin's lymphoma & $6 \%$ \\
\hline & Hodgkin's lymphoma & $1 \%$ \\
\hline & Metastatic deposit to LN & $6 \%$ \\
\hline \multirow{4}{*}{$\begin{array}{l}\text { Thyroid lesions } \\
\text { (57\%) }\end{array}$} & Cystic & $2 \%$ \\
\hline & Goitre & $38 \%$ \\
\hline & Thyroiditis & $9 \%$ \\
\hline & Malignant & $8 \%$ \\
\hline \multirow{3}{*}{ Soft tissue $(15 \%)$} & Lipoma & $6 \%$ \\
\hline & Abscess & $7 \%$ \\
\hline & Spindle cell tumour & $1 \%$ \\
\hline Salivary gland (1\%) & $\begin{array}{l}\text { Mucoepidermoid carcinoma } \\
\text { Submandibular gland }\end{array}$ & $1 \%$ \\
\hline \multicolumn{3}{|c|}{ Table 3. Incidence based on Pathology } \\
\hline
\end{tabular}

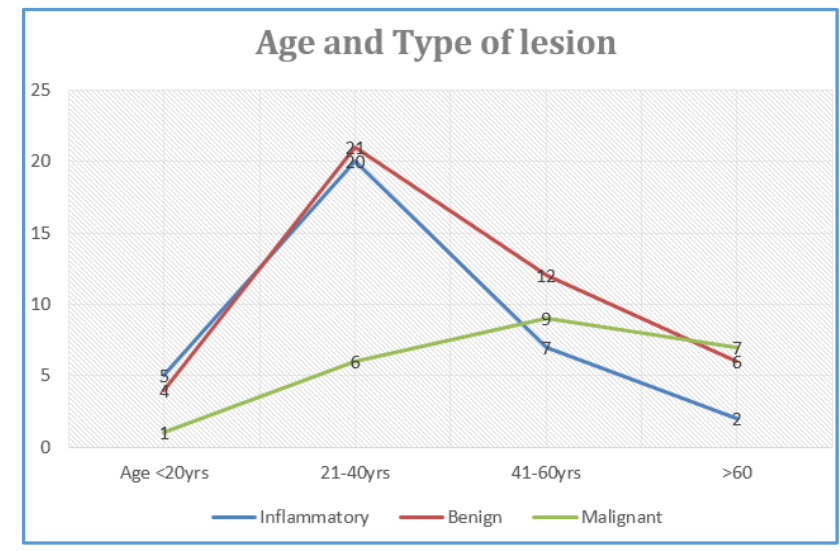

Figure 5. Distribution of Age and type of Lesion

\begin{tabular}{|c|c|c|c|}
\hline Origin & Male & Female & N= 100 \\
\hline Lymph Node & 20 & 7 & $27 \%$ \\
\hline Thyroid & 9 & 48 & $57 \%$ \\
\hline Salivary & 0 & 1 & $1 \%$ \\
\hline Soft Tissue & 10 & 5 & $15 \%$ \\
\hline Table 4. Correlation between Sex and Tissue of Origin \\
\hline
\end{tabular}

Data expressed as percentage and absolute numbers.

\begin{tabular}{|c|c|c|c|}
\hline & Male $\mathrm{N}=37$ & $\begin{array}{c}\begin{array}{c}\text { Female } \\
N=63\end{array}\end{array}$ & $\begin{array}{c}\text { Total } \\
\mathbf{N}=\mathbf{1 0 0}\end{array}$ \\
\hline TB/Granulomatous LN & 10 & 1 & 11 \\
\hline Reactive lymphadenitis & 3 & 1 & 4 \\
\hline Non-Hodgkin's lymphoma & 3 & 2 & 5 \\
\hline Hodgkin's lymphoma & 1 & 0 & 1 \\
\hline Metastatic deposits & 3 & 3 & 6 \\
\hline Goitre & 4 & 34 & 38 \\
\hline Thyroiditis & 1 & 8 & 9 \\
\hline Malignant & 1 & 7 & 8 \\
\hline Lipoma & 3 & 3 & 6 \\
\hline Primary skin malignancy & 1 & 0 & 1 \\
\hline Abscess & 5 & 2 & 7 \\
\hline \multirow[t]{2}{*}{ Spindle cell tumour } & 1 & 0 & 1 \\
\hline & 0 & 1 & 1 \\
\hline \multicolumn{4}{|c|}{$\begin{array}{c}\text { Table 5. Correlation between Sex based on Pathological } \\
\text { Diagnosis }\end{array}$} \\
\hline
\end{tabular}

Data expressed as absolute numbers.

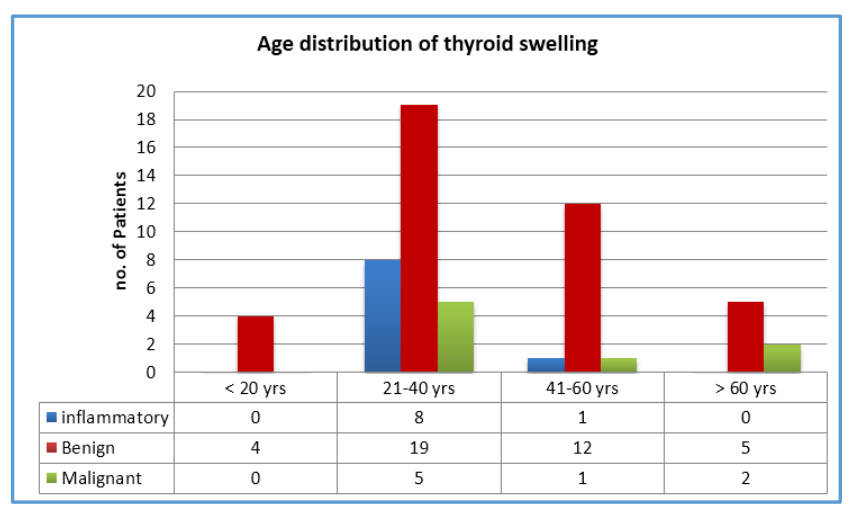

Figure 6. Age distribution of Thyroid Swelling 
Data expressed in absolute numbers.

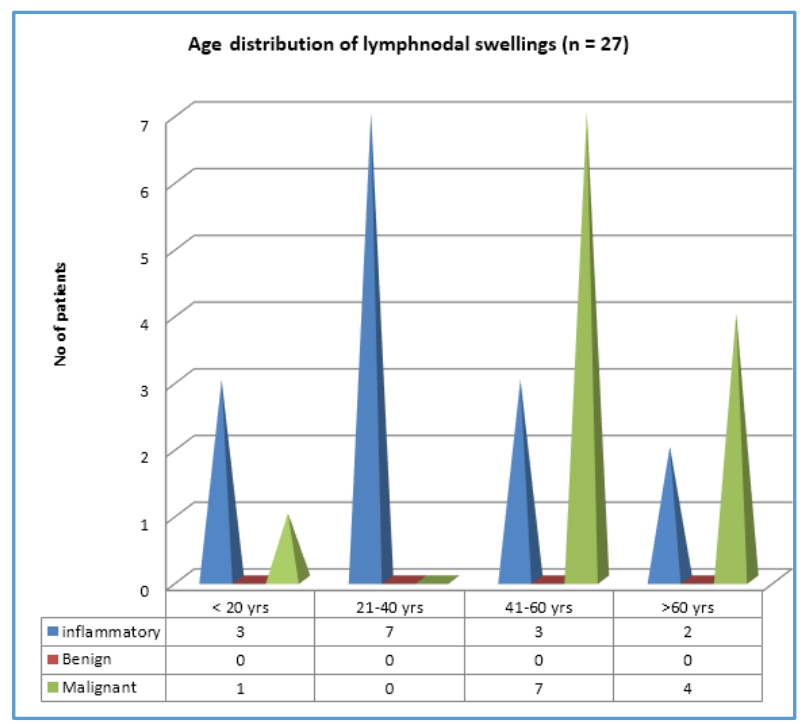

Figure 7. Age distribution of Lymph Nodal Swellings

Data expressed as absolute numbers.

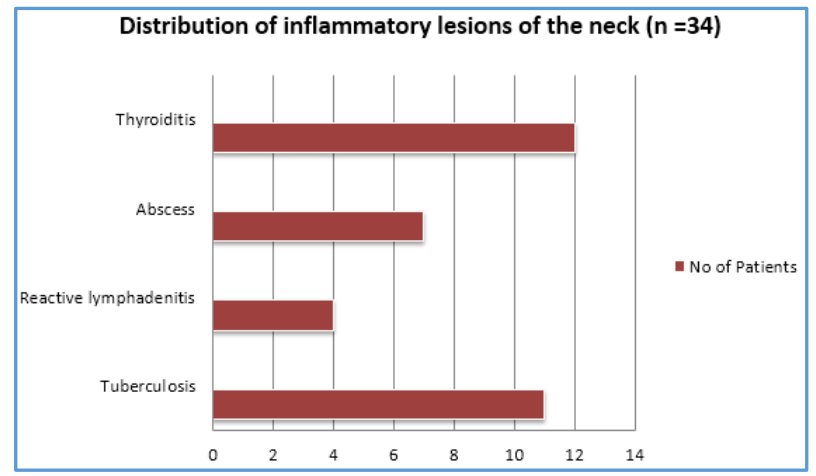

Figure 8. Distribution of Inflammatory Lesions of the Neck

\begin{tabular}{|c|c|c|}
\hline Pathological Diagnosis & & No. \\
\hline Lipoma & & 6 \\
\hline \multirow{4}{*}{ Thyroid } & Cystic lesions & 2 \\
\cline { 2 - 3 } & Colloid nodule & 4 \\
\cline { 2 - 3 } & Follicular neoplasm & 8 \\
\cline { 2 - 3 } & Nodular goitre & 16 \\
\cline { 2 - 3 } & Thyroglossal cyst & 1 \\
\hline \multicolumn{2}{|c|}{ Total } & 37 \\
\hline \multicolumn{2}{|c|}{ Table 6. Distribution of Benign Lesions based on } \\
Pathological Diagnosis \\
\hline
\end{tabular}

Data expressed as absolute numbers.

\begin{tabular}{|c|c|c|}
\hline Tissue & Pathological Diagnosis & Total \\
\hline \multirow{3}{*}{ Lymph node } & Metastatic carcinoma & 6 \\
\cline { 2 - 3 } & Non-Hodgkin's lymphoma & 5 \\
\cline { 2 - 3 } $\begin{array}{c}\text { Thyroid } \\
\text { gland }\end{array}$ & Hodgkin's lymphoma & 1 \\
\cline { 2 - 3 } Soft tissue & Papillary carcinoma & 6 \\
\cline { 2 - 3 } & Anaplastic carcinoma & 1 \\
\cline { 2 - 3 } & Rhabdomyosarcoma & 1 \\
\hline $\begin{array}{c}\text { Salivary } \\
\text { gland }\end{array}$ & $\begin{array}{c}\text { Submandibular (mucoepidermoid } \\
\text { carcinoma) }\end{array}$ & 1 \\
\hline \multicolumn{2}{|c|}{ Total } & \multicolumn{2}{|c|}{\begin{tabular}{c} 
carcinoma) \\
\hline Table 7. Distribution of various Malignant Lesions of Neck
\end{tabular}} \\
\hline
\end{tabular}

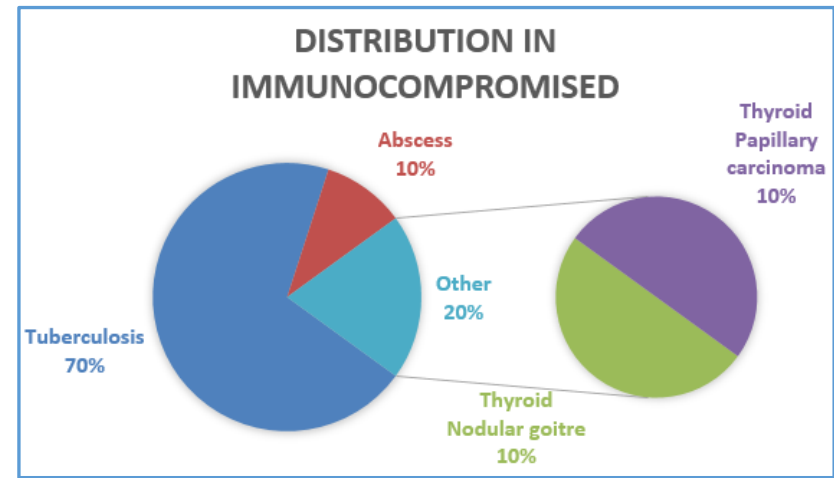

Figure 9. Nature of Lesion in Immunocompromised

Clinical Photographs of the Patients

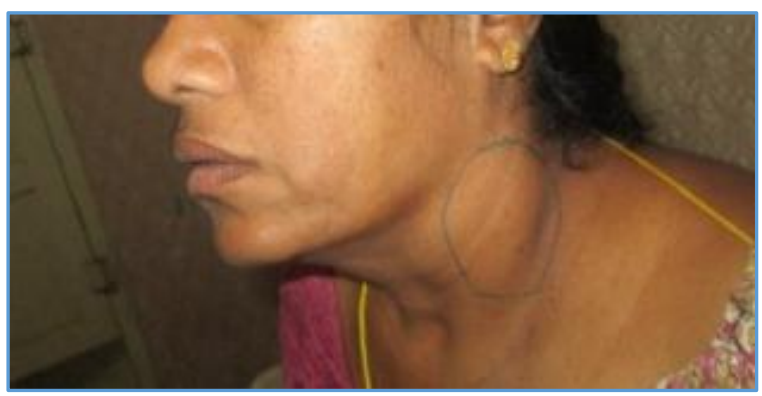

Figure 10. Clinical Photograph of patient showing Metastatic deposit (Squamous Cell Carcinoma) in Cervical Nodes

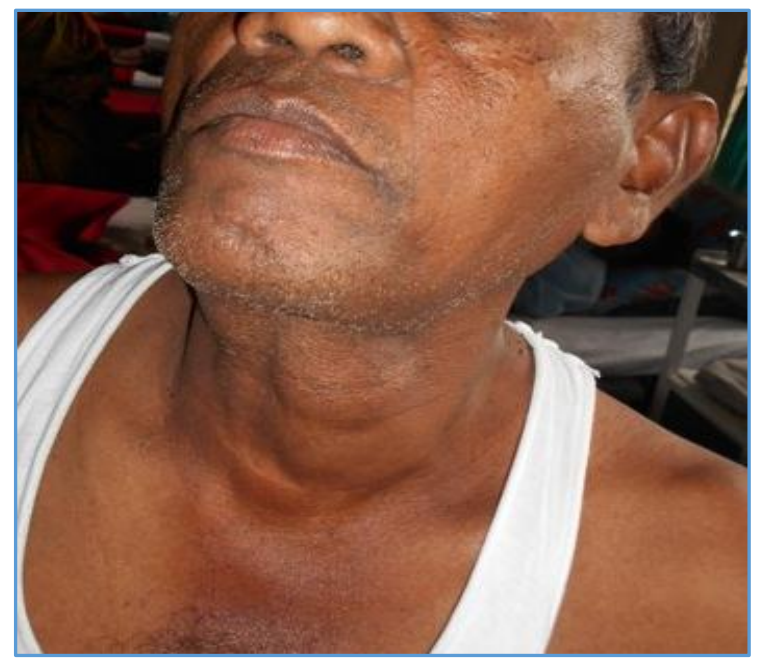

Figure 11. Clinical Picture of another patient showing Metastatic secondary deposits in Neck

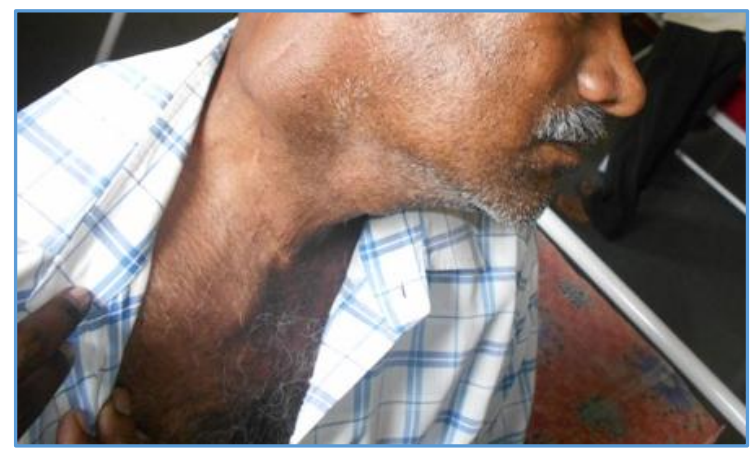

Figure 12. Clinical Picture of the patient showing TB Lymphadenitis 


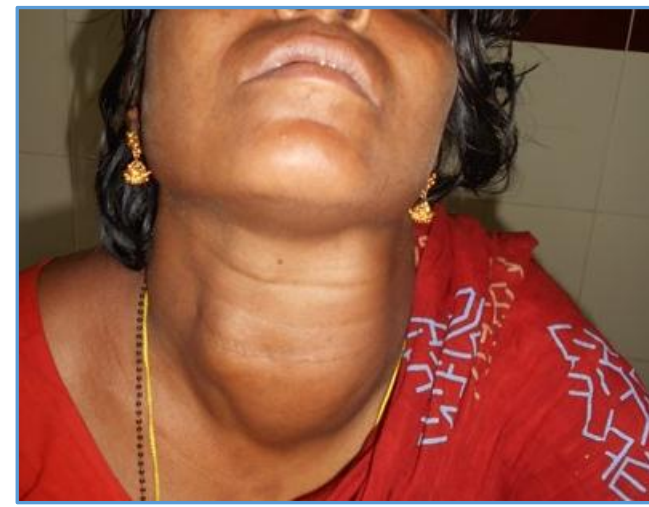

Figure 13. Clinical Picture of the patient showing Nodular Goitre

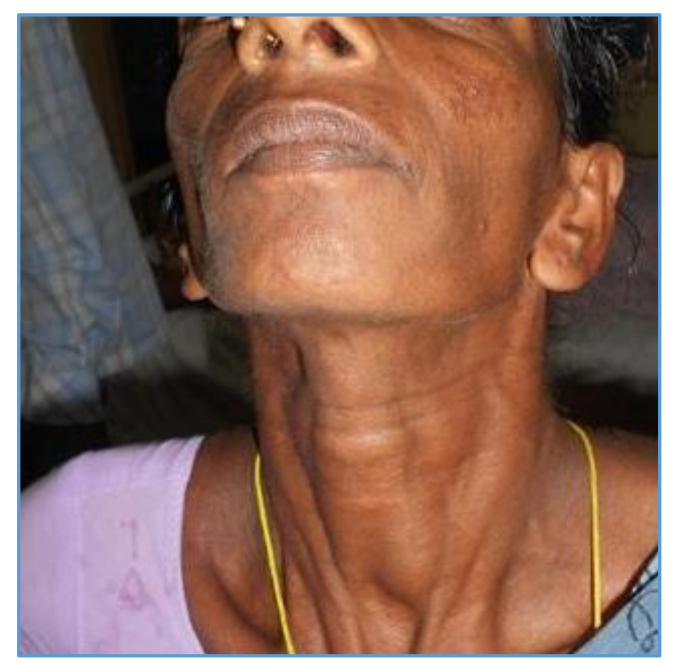

Figure 14. Clinical Picture of the patient showing Colloid Nodule of Thyroid

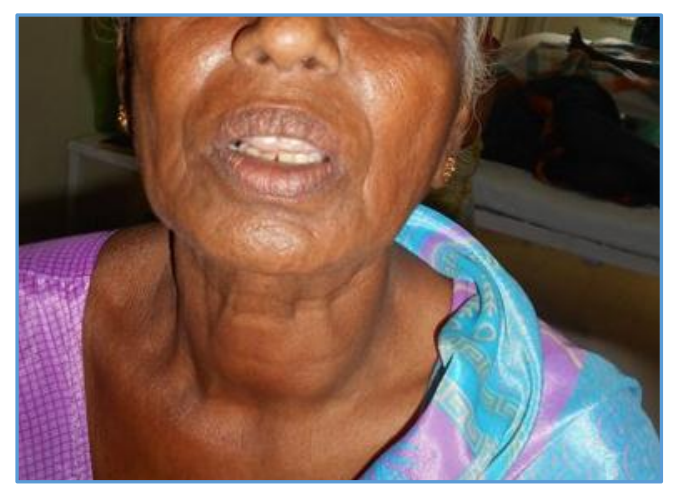

Figure 15. Clinical Picture of patient showing Thyroiditis

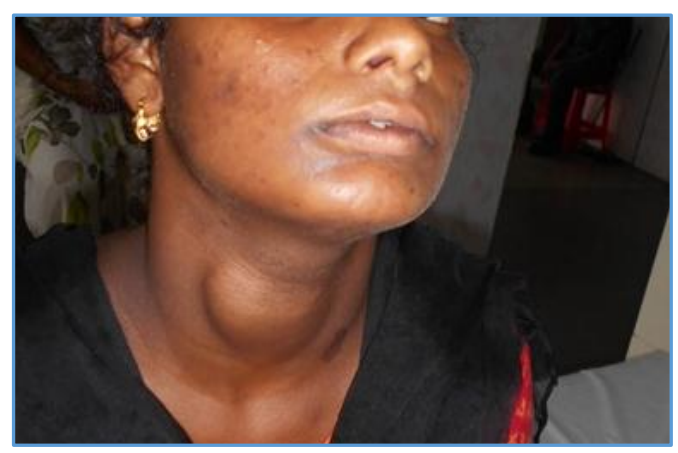

Figure 16. Clinical Picture of the patient showing Papillary Carcinoma Thyroid

\section{DISCUSSION}

Most of the catchment of the Government General Hospital is from the rural areas. The people from these rural areas have low socioeconomic status and mostly uneducated. Most of the males regularly chew tobacco and smoke. Mostly, females are house-bound and ignorant about their health and nutrition. So infectious and malignant conditions constitute a significant proportion of health problems among them.

Diagnostic cytology when performed by well-trained experienced individual offers a high degree of reliability and feasibility. In our study, the spectrum of lesions observed from the neck confirms its utility as an effective tool in the diagnostic workup of this area.

The present study was demonstrated that there was clear female preponderance in the incidence of neck swellings. Although, there were many clinical studies that reported uneven data regarding gender distribution, this study was comparable to the study of Modi et al, Soni et al and Ahmad et al, whose studies showed female preponderance.9,10,11 The youngest patient was 15 yrs. old and oldest was 84 yrs. and mean age being 41.5 yrs. Age distribution of the swellings when assessed showed clustering of the lesions from the age group of 20 yrs. to 40 yrs. in the active period of one's lifetime. This could be because of the physiological demand that could not meet the daily demands of the patients who are mostly undernourished manual labourers below poverty line. This study results were comparable to the study done by Hitendar Basista et al and Manjula et al.12,13 The inflammatory and benign lesions were found to be most common below the age of 40 yrs. The prevalence of malignant lesions rose sharply after $4^{\text {th }}$ decade, which is expected as the same happens in rest of the body. ${ }^{14}$

Total of 100 neck swellings were evaluated, out of which 57 swellings were of thyroid origin, 27 were of lymph nodal origin, 15 were of soft tissue origin and 1 was of salivary gland origin. This study showed clear preponderance of thyroid swellings over lymph nodal swellings. Though many other studies had lymph nodal swellings in greater proportion. This study showed thyroid swellings in dominant proportion that too in female sex. ${ }^{15,16,17}$ This study was comparable to study done by Hitendar Basista et al, where thyroid was the most common tissue of origin of lesion. The most common single pathological diagnosis was goitrous lesion of thyroid (38\%) followed by Tuberculous affection of lymph node $(11 \%)$. Our results were comparable to the study by Hitender Basista et al. Many of the other studies in the literature showed predominance of tubercular lymphadenitis as in studies by Ahmad et al, Garima Gupta et al and reactive lymphadenitis in study by Manjula et al. ${ }^{18}$ However, the incidence of Tubercular lymphadenitis in our study was $11 \%$ and is still comparable to studies of Manjula et al (16.84\%) and Jindal et al (19.84\%).

Our Government General Hospital caters most of the patients from fluorosis endemic areas. This might be the reason for higher prevalence of Iodine deficiency disorders such as thyroid goitre. ${ }^{19}$ The fluoride endemicity coupled with higher malnutrition and ignorance about health in females might prove as the reason for female gender preponderance of neck swellings. ${ }^{20,21}$

The inflammatory lesions contributed to $34 \%$ of cases in our study. This is in contrast to $74.66 \%$ in study by Garima Gupta et al, the reason being the predominance of benign 
thyroid lesions in our study. Tubercular affection of lymph node and abscess, i.e. the infective ones (53\%) occupied the majority of inflammatory lesions, malnutrition and health ignorance the most plausible reasons.

It was found that tubercular affection of lymph node below the age of $40 \mathrm{yrs}$. and malignancy above the age of 40 yrs. are the most common reasons for lymph node swelling. Thus, a high index of clinical suspicion and FNAC can make the diagnosis closer without advanced tests.22,23 Advanced tests such as ELISA and PCR are costly and not available in public sector setting.

In our study, the malignant lesions comprised $22 \%$ of the neck masses. Frequency of incidence in different studies vary from $7.5 \%$ to $38.6 \%$. Lymph node malignant lesions comprised of Metastatic deposits, Hodgkin's and NonHodgkin's lymphoma. Metastatic deposits to the lymph nodes were mostly from squamous cell carcinoma elsewhere.24 Thyroid malignancies were mostly papillary carcinomas (80\%), which were found to be more common in females $<40$ years. ${ }^{25}$ Among the salivary gland lesions, one case of mucoepidermoid carcinoma was reported. Our results of thyroid and salivary gland malignancies were found similar to the study of Jindal et al.

Lipoma was found to be the most common benign soft tissue lesion of neck (6\%). It could be considered similar to the studies of Manjula et al and Jindal et al.

Immunocompromised patients were found to be more commonly inflicted with tuberculous affection of lymph node amongst the neck swellings. Lack of immunity predisposes them to secondary activation of tuberculosis.

\section{To Summarise}

- The most common tissue of origin of neck swelling was found to be thyroid.

- The thyroid swellings showed a clear female preponderance, and this translated to the whole sample.

- The most common single pathological diagnosis was Goitrous lesion of thyroid followed by tuberculous affection of lymph node.

- $\quad$ Lymph node swelling of neck below the age of 40 years is more likely to be tubercular and above the age of 40 years to be malignant.

- Secondary deposits to lymph node is more likely from squamous cell carcinoma elsewhere.

- Papillary carcinoma is the commonest of thyroid malignancies and is more commonly found in females of age $<40$ years.

- Neck masses in immunocompromised patients are more likely to be due to infective aetiology and tuberculosis in particular.

\section{CONCLUSION}

The most common single pathological diagnosis in our study was found to be Goitrous lesion of thyroid, most likely attributed to the endemicity of fluorosis in the catchment area of the hospital. High index of suspicion of malignancy needs to be borne in mind in dealing with a lymph node swelling in elderly. Fine needle aspiration cytology clubbed with ultrasonography offers simple methods of diagnosis of neoplastic and non-neoplastic lesions in the neck to confirm clinical diagnosis. It can be performed as an outpatient procedure without complications. The procedure is acceptable to most of the patients. There is no need for anaesthesia and results can be made available within short duration of time.

\section{REFERENCES}

[1] Roland N, Bradley PJ. Neck swellings. BM] 2014;348:g1078. 10.1136/bmj.g1078, 348:g1078.

[2] Rosenberg TL, Brown JJ, Jefferson GD, et al. Evaluating the adult patient with a neck mass. Med Clin North Am 2010;94(5):1017-29.

[3] Orell SR, Sterrett GF, Walters NI, et al. Manual and Atlas of FNAC. 2nd edn. New York: Churchill Livingstone 1995: p. 250.

[4] Watkinson JC, Wilson JA, Gaze M, et al. Stell and Maran's Head and neck surgery. Chap - 2 and 20-21. $4^{\text {th }}$ edn. Oxford: Butterworth-Heinemann 2000.

[5] Afridi S, Malik K, Wahed I. Role of fine needle aspiration biopsy and cytology in breast lumps. J College of Physicians and Surgeons Pakistan 1995;5:75-7.

[6] Burnand KG, Young AE, Lucas J, et al. The new Aird's companion in surgical studies. $3^{\text {rd }}$ edn. China: Elsevier 2005.

[7] Layfield LJ. Fine-needle aspiration of the head and neck. Pathology (Phila) 1996;4(2):409-38.

[8] Kirk RM, Ribbans WJ. Clinical surgery in general. $4^{\text {th }}$ edn. Edinburgh: Elsevier 2004.

[9] Modi P, Oza H, Bhalodia J. Utility and adequacy of fine needle aspiration cytology in head and neck lesions: a hospital based study. Int J Sci Stud 2014;2:100-5.

[10] Soni S, Pippal SK, Yashveer B, et al. Efficacy of fine needle aspiration cytology in diagnosis of neck masses. World Articles in Ear, Nose and Throat 2010;3:1. www.waent.org

[11] Ahmad T, Naeem M, Ahmad S, et al. fine needle aspiration cytology (FNAC) and neck swellings in the surgical outpatient. J Ayub Med Coll Abbottabad 2008;20(3):30-2.

[12] Basista H, Modwal A, Prasad B. Clinicopathological evaluation of neck masses. Sch J App Med Sci 2015;3(9B):3235-41.

[13] Manjula K, Prasad CSBR, Gayathri BN, et al. Cytomorphological study of lateral neck swellings. Journal of Clinical and Diagnostic Research 2011;5(5):1016-9.

[14] Jindal U, Singh K, Baghla A, et al. Spectrum of head and neck swellings in the rural population of India based on fine needle aspiration findings. The Internet Journal of Head and Neck Surgery 2012;5:2.

[15] El-Hag IA, Chiedozi LC, al-Reyees FA, et al. Fine needle aspiration cytology of head and neck masses. Seven year's experience in a secondary care hospital. Acta Cytol 2003;47(3):387-92.

[16] Lawrence C, Imad AH, Shara NMNM. Study of Fine Needle Aspiration of head and Neck masses. Acta Cytol 2003;47:387-92.

[17] Muddegowda PH, Srinivasan S, Lingegowda JB, et al. Spectrum of cytology of neck lesions: comparative study from two centers. Journal of Clinical and Diagnostic Research JCDR 2014;8(3):44-5.

[18] Gupta G, Joshi DS, Shah A, et al. FNAC of head and neck swellings. GCSMC J Med Sci 2014;3(1):38-41. 
[19] Hetzel BS, Potter BJ, Dulberg EM. The iodine deficiency disorders: nature, pathogenesis and epidemiology. World Rev Nutr Diet 1990;62:59-119.

[20] Kuna SK, Bracic I, Tesic V, et al. Ultrasonographic differentiation of benign from malignant neck lymphadenopathy in thyroid cancer. J Ultrasound Med 2006;25(12):1531-7.

[21] Knox MA. Thyroid nodules. Am Fam Physician 2013;88(3):193-6. http://www.btf-thyroid.org/. lump, Neck and NICE CKS, February 2010.

[22] Sheahan P, Fitzgibbon JG, O'Leary G, et al. Efficacy and pitfalls of fine needle aspiration in the diagnosis of neck masses. Surgeon 2004;2(3):152-6.
[23] Cheng ATL, Dorman B. Fine needle aspiration cytology: the Auckland experience. Australian and New Zealand Journal of Surgery 1992;62(5):368-72.

[24] Goyal A, Tiwari RS, Desai AA. Diagnostic role of ultrasonography in neck swellings. Indian Journal of Otolaryngology and Head \& Neck Surgery 1999;51(4):67-71.

[25] Gupta A, Ly S, Castroneves LA, et al. A standardized assessment of thyroid nodules in children confirms higher cancer prevalence than in adults. J Clin Endocrinol Metab 2013;98(8):3238-45. 